\title{
Neoliberalism, Nationalism and the Decline of Political Traditions
}

\author{
COLIN CROUCH
}

\begin{abstract}
The three great Western political traditions (conservatism, liberalism, social democracy) incorporate three of the four possible combinations of the core political axes: traditional, unchanging authority versus the challenge of change, and egalitarianism versus inegalitarianism. The fourth possibility - egalitarian conservatism-has appeared in various guises, but has usually become submerged within the right, including its most authoritarian forms. Current xenophobic movements claiming to represent those suffering from excessive changefor example, those involved in the UK's EU referendum and Donald Trump's victory in the USA - are seeing an apparent resurgence of this neglected tradition. What are its implications for politics in general?
\end{abstract}

Keywords: conservatism, (neo)liberalism, nationalism, social democracy, Brexit, xenophobia, egalitarianism

THE GREAT political traditions that we inherited from the nineteenth and twentieth centuries are fragmenting, and there is a general downward trend in participation in elections. How viable today is the classic conservative, social-democratic and liberal triangle to which we have long been accustomed? In particular, as far-right parties move towards supporting the welfare state, are we seeing the emergence of a missing fourth limb of political ideologies: egalitarian conservative nationalism? If so, what are its implications for the others?

The approach to political traditions that I take here owes much to David Marquand's Mammon's Kingdom. ${ }^{1}$ His concerns are broader than this. First, he offers a trenchant critique of the moral impoverishment towards which the neoliberal political ideology of successive governments since the 1980s brought the United Kingdom. Second, in asserting the importance of collective and public values against this dominant ideology, he makes a profoundly useful point: most people will be best able to grasp the importance of these values if they can relate them to their own lived experience and their historical legacies from national political traditions, rather than through abstract argument. Third, he invokes all three of the great political families of modern British history-conservatism, liberalism and socialism -and sees them not just as the basis of opposed parties, but as open traditions capable of sharing perspectives. As a result, his book is extremely useful in helping us understand how those traditions, and relations among them, are affected by the two powerful vortices into which they have been thrown: neoliberalism and the resurgence of nationalism.

In seeking this understanding, I shall move beyond specifically British experience. While Marquand's argument that people experience politics primarily through specific and usually national contexts is entirely valid, it is both analytically and politically important not to see national political traditions as hermetically sealed against each other. We are clearly able to communicate about political institutions across national boundaries, even though that communication is full of errors and misunderstandings. There are layers of meaning in these complex terms, ranging from highly specific, almost private ones through to those more easily shared, with a constant trade-off between communicability and richness of meaning. 
It is therefore possible, with Marquand, to grasp the national specificity of British approaches to the collective and the public without denying that other traditions have their own, different but similar, ones. The Swedish concept of folkshemmet, literally 'the people's home', is a distinctive way of understanding the welfare state: we are all at home, part of a family, in our country, and so we care for each other. But it is not impossible for a British person to relate that to at least the original Beveridgian welfare state, if not its meaner, narrower contemporary formulation. The German idea of staatstragende Kräfte, 'state-bearing powers', conveys the idea that certain non-governmental institutions in civil society (such as churches and trade unions) can perform public tasks and join the state to civil society. This is different from the British concept of institutions like the $\mathrm{BBC}$ or perhaps the National Trust, which are part of a wider sense of the public than that conveyed by the state itself, but it is similar, and Germans and Britons ought to be able to understand the shared as well as the diverse parts of their institutional legacies. We should be able to see specific, perhaps national, interpretations of political and other ideas as enfolded in broader, more general ones-somewhat like a Russian doll, except that the different levels are not identical. From that comes the possibility of constructing shared transnational political institutions and traditions.

Thus, although the three great traditions of conservatism, liberalism and socialism exist in highly varied forms across cultures, at a very basic level these terms have a shared meaning in many political systems, certainly across western Europe, and (with some further loss of content) across North America and eastern Europe as well. It is also a remarkable fact that most democratic political movements of the late nineteenth and the twentieth centuries can be related to one or more of them.

\section{The triangle of political traditions}

For convenience within a short article, the three traditions shall be described as follows. (A more detailed and richer account of what these traditions mean, particularly in the British case, will be found in Marquand's book.
It should be noted that I here follow him in being concerned with traditions, that is, ideas and institutions that have emerged from specific historical experiences, and not with abstract ideologies.) Political parties are highly important manifestations of these traditions, but they are not coterminous with them.

Conservatism represents a preference for institutions inherited from the past, imbued with the rich patina of tradition and slow accumulations from specific, mainly national, contexts. Michael Oakeshott once contrasted conservatism with idealism by claiming that while the idealist wants to say, with Goethe's Faust, 'Verweile doch, du bist so schön' ('Stay a while, you are so beautiful'), the conservative is content with 'Stay with me, for I have become attached to you'. ${ }^{2}$ This is not the usual meaning given to conservatism by its opponents, who see it rather as the defence of privilege. It is indeed also that, but adding Oakeshott's approach enables us to understand how and why conservatism can be attractive to people way beyond the ranks of the privileged.

Liberalism, conservatism's original nemesis in European history, stands for the rights of the individual, particularly in the context of rejection of the constraints imposed by conservatism and its elites. As such, liberalism is not necessarily opposed to collective action or public goods, and certainly not synonymous with the market, but market freedoms often represented resources that had not been captured by conservative elites, and were therefore important to their opponents. As market power became established and absorbed into conservatism's ambit, liberals became divided between those who still identified conservatism as a barrier to human liberation and those for whom the main thing was the defence of private property, especially that acquired through market transactions.

Socialism was a daughter of liberalism in the latter's confrontation with conservatism, but it represented the interests of those too poor to be able to use their individual power. Instead they had to seek collective action, both to provide a basis of solidarity to support their individual weakness and to provide an instrument for reducing the inequalities created first by conservatism and later by market liberalism. 
While theory and ideology can elaborate any or all of these traditions at will, when they manifest themselves in the real worldwhether as parties, movements or sets of policies - they nearly always have to compromise with each other, or are by the preference of their participants hybrids between two or all three. It is therefore useful to represent them as the three points of a triangle, the overall space defined by the triangle representing the total combination of politics and policies available within a particular universe. Extreme, uncompromising forms exist at the three points. Compromises between two run along the lines connecting two points; those among all three occupy various parts of the overall triangular space. The theory of the median voter, whichhaving its origin in the US - sees politics as a choice between only two options, neither of which has much intrinsic meaning, proposes that parties will try to locate themselves at the centre of a straight line. ${ }^{3}$ The equivalent theory applied to a three-pointed space would propose that all parties will try to position themselves in the centre of the triangle, because from there access can be had to all voters. When we are concerned with parties, or other institutions needing to build coalitions of support, it is certainly likely that no major movement will restrict its appeal entirely to one or even two of the three points in the triangle. As a result, over time each tradition develops points of access to, and therefore potential compromise with, each of the others. An interesting example is the way in which, during the first five decades of the postwar Italian republic, when the Communist party was excluded from sharing in government and relations between it and the dominant Christian Democrats were very hostile, both sides were careful to maintain 'windows' of communication. Also, as will be explored at some points below, each tradition is vulnerable to being left isolated by coalitions of the other two. This too provides an incentive to maintain relationships.

On the other hand, complete clustering at the centre is also unlikely to happen. Sometimes parties simply do not want to appeal to certain parts of the spectrum; at other times, the contradictions involved in trying to widen parties' appeals from their bases stretch both plausibility and the tolerance of parts of their existing support. The traditions remain as Marquand describes them: separate but sharing certain themes and concerns.

Although historically liberals and conservatives have been opposed to each other, in many countries much of the twentieth century was dominated by alliances between them, whether in actual coalitions between parties (as was often the case in Belgium, Germany and the Netherlands) or as factions within parties (as in Fifth Republic France and the UK). The two came together to resist the egalitarian challenge from socialist forces, since in a capitalist economy both liberalism and conservatism tend to represent the interests of those who benefit from only a limited redistribution of wealth and power. Conservatives were concerned at the change and disruption caused by the unchecked operation of market freedoms, but in the early postwar years Christian democrats (the main anti-fascist form taken by continental European conservatism) feared a secular alliance of liberals and socialists, and renounced much of their earlier opposition to capitalism. In order to govern in democracies, conservatives and liberals then also had to make concessions to elements of the socialist agenda, particularly in terms of reducing uncertainty in the lives of working people. Various versions of a welfare state became part of national consensuses. This coalition of ideas, forces and policies, existing mainly along the conservative-liberal limb of the triangle but moving off a little towards elements of socialism, became the most successful governing concoction in postwar western Europe, its motley nature being the price paid for, and probably the guarantee of, its dominance.

Alliances between liberals and socialists can result from liberals' unease at the effect of unchecked inequality on many individuals, and also from socialists' own unease at the repressive tendencies of their own advocacy of state power. Indeed, the dominant form of socialism in twentieth-century western Europe - social democracy - can itself be seen as positioned some way up the socialism-liberalism limb of the triangle, rather than at the socialist pole. Further, anticonservative alliances, more often in the 
form of ideas and policies rather than formal coalitions, have steered many important political developments of the past four or so decades. Changes in laws concerning contraception, abortion, divorce, homosexuality, the rights of women, immigrants and ethnic minorities have all constituted defeats for traditional conservatism at the hands of liberals and social democrats, to the extent that most conservatives have abandoned their historical positions.

Tacit alliances between liberalism and social democracy can also be found in the approaches of international institutions of economic governance. It is difficult for the Organisation for Economic Co-operation and Development (OECD), the World Bank, the International Monetary Fund (IMF) or the European Union (EU) to be conservative in the full sense. Conservatism draws primarily on national traditions and is uncomfortable with transnationalism, a stance that is not available to these bodies. These organisations' politics therefore tend to oscillate between social democracy and liberalism. During the Keynesian period, they expressed that compromise, with all its tensions. They later increasingly rejected most socialdemocratic policies, becoming neoliberal (the emphasis being heavily on the marketmaking aspects of liberalism). In the early twenty-first century, evidence that growing inequality may be threatening economic growth, especially in the USA, is producing something of a turn back to socialdemocratic concerns at the OECD, IMF and World Bank; less so in the EU. ${ }^{4}$

There is, or has been, a different situation for many continental European conservatives, in that fascism and Nazism discredited their nationalist traditions, and they sought to rebuild non-nationalistic forms of them on a European level. This was relatively easy for the postwar founders of what has become the EU, as most of them were Roman Catholics, and Catholicism has always required loyalty to nation to be incorporated within that to a wider, transnational institution-the Church. This helps to explain the greater difficulty that British and Scandinavian conservatives have had in coming to terms with European integration, with the majority (though by no means all) of them having no fascist past, and given their heritage of national Protestant churches.

Compromises along the conservativesocialist axis may seem the least likely, but they have been important. Although socialists have, like liberals, been associated with change, they are concerned for the stability of working people's lives. This includes not just the economic stability that can be ensured by a welfare state, but also the frequent feeling among people who do not possess much social power that they cannot control what is going on around them. They will often share Oakeshott's sentiment quoted above. At the present time, these feelings are particularly strong among parts of the population affected by neoliberal change, such as the decline of occupations and communities in manufacturing and mining and the impact of immigration resulting from liberalised labour markets. Formally, social democracy has been internationalist and hostile to all forms of xenophobia. However, its main institutional achievements have been profoundly if tacitly national, in the form of national welfare states. When social democrats become passionate about the need for rights and benefits to be 'universal', their universe nearly always stops at the national border. In the mid-twentieth century, when these institutions were being constructed, the point did not carry many implications, as virtually all social policy was implicitly limited to an established, more or less native population. Social-democratic governments then had no difficulty extending coverage to small numbers of immigrants. However, as numbers of immigrants have risenparticularly in the Nordic countries, which have welcomed many refugees from the Arab world and North Africa-the national quality of universalism comes into question. Potential alliances with nationalist conservatism cannot therefore be excluded.

It is at this point that one asks why the basic shape of political traditions is a triangle, and not the square that results from social science's normal two-by-two matrix. There are the usual two pairs of variables: for or against challenge to established power-holders and for or against egalitarianism. Grosso modo, conservatism represents the inegalitarian defence of the privileged against change; liberalism (at least in its 
currently dominant neoliberal form) the defence of the economically privileged through change; social democracy the egalitarian defence of the underprivileged through change. The missing quadrant is egalitarianism against change, which has rarely developed an autonomous tradition. It is a position with a logical difficulty, in that the underprivileged can hardly be helped if society does not change. In practice, social democracy and conservatism adjust their appeals to embrace this anomaly-with different levels of success at different periods. In that way, the triangle remains. However, if conservatism defines itself essentially as nationalistic, and in particular as hostile to ethnic and foreign minorities, who can be depicted as threatening a cherished way of life, the prospects for egalitarian conservative nationalism appear far more promising. This needs to be distinguished from the egalitarian liberal nationalism that flourished during the nineteenth and early twentieth centuries in Italy and many parts of central Europe as various nationalities struggled to liberate themselves from the Austro-Hungarian Empire. These movements might have hearkened back to earlier traditions and therefore contained an element of conservatism, but such traditions were not embedded in existing networks of power. A similar point applies to some of the current nationalisms that are entering serious politics in Catalonia, Scotland and elsewhere. To determine whether these are liberal or not requires more detailed discussion than is possible here, but the continuing viability of forms of liberal nationalism needs to be borne in mind.

Closer to egalitarian conservative nationalism have been other, quite diverse movements. Here one finds the Catholic labour movements that developed in France, Germany, Italy and elsewhere from the late nineteenth century and, more recently, the radical Catholic trade union movement, Solidarność, which helped bring down communist dictatorship in Poland. Very different were the anti-capitalist, pro-welfare components of the interwar fascist movements. Benito Mussolini, Oswald Mosley, René Belin (former trade union leader and Minister for Social Affairs in the Vichy regime) and Hendrik de Man (Belgium's leading socialist theorist, who became a fascist) all came into fascism from socialist parties. Among the factions creating the German National Socialist Party was the strongly anti-capitalist and violent Sturmabteilung (SA). More ambiguous than these was Juan Perón, whose movement still constitutes the political left in Argentina, but who found sanctuary in fascist Spain during his exile in the 1950s. The fourth pole, egalitarian conservatism and/or nationalism, clearly exists as a historical phenomenon. Its problems are its extraordinary internal diversity, which depends very much on whether its conservative inspiration is Christian, nationalist or something else, and its historical inability to establish itself as a stable political force autonomous of its more straightforward inegalitarian counterpart. The assassination of the SA's leaders on Hitler's orders during the 'night of the long knives' in 1934 stands as the most dramatic example.

This brief summary demonstrates the kaleidoscopic nature of relations among the three great political traditions of Western societies, and the fragmentary fourth one. When they are refracted through the organisation of political parties, they become particularly complex. Parties are formed at one period of history, representing the feasible coalitions of that time, but live on into periods with different power combinations and in which new issues are confronted. The parties are themselves affected by these changes, but, through the strength of their organisational capacity, they can often prevent any rapid adaptation of politics to the emerging new society, preserving alliances among what have become highly contradictory forces.

\section{The decline of the traditions}

Although the great traditions continue to define and dominate politics of all kinds, and especially electoral politics, they all suffer from major weaknesses. Those of liberalism are the longest running. Although liberals were the main advocates of extending the franchise in the late nineteenth century, and although their ideas continue to play a major role, their parties were the main victims of the growth of democracy. In an article published in 1976, Matthew, McKibbin and Kay identified the main causes of

Neoliberalism, Nationalism and the Decline of Political Traditions 225 
the liberal paradox in the particular case of Britain. ${ }^{5}$ They proposed that the Liberal party's political language of reasoned argument was suited only to small, elite electorates, and could not appeal to large masses of the population. Liberals could rival neither the emotional appeal to national and religious loyalties of the Conservatives nor the appeal to class solidarity of the Labour party. The Liberals moved from being the country's dominant party in the early twentieth century to becoming its small third force by the 1920s, a position from which the party never recovered. Similar stories can be told of other western European countries, altered only a little by differences in electoral systems. Almost nowhere, whether in Europe or elsewhere, can parties primarily definable as liberal be considered 'major'. Canada is the main exception, though there the Liberal party also depends strongly on support from the French-speaking electorate, rather than on liberalism as such. A similar point can be made about any claims on the part of the US Democrats to be a liberal party rather than one based on various kinds of ethnic support. The only country in Europe in which a liberal party is currently the largest one in the system is the Netherlands, but that is a country with no truly dominant parties.

Major defects in the support bases of conservatism and socialism (or social democracy) have appeared more recently. In most of Europe, west and east, the Christian religion has declined very heavily over the past thirty to forty years, taking with it important conservative values regarding the family, sexual relations and the role of women. The story is very different in the USA, where certain forms of Christianity and their associated attitudes regarding these other issues have grown in importance, becoming central components of Republican (white) and Democratic (black) support. But for a longer period, established conservatives in both Europe and the USA have had to accept that they can no longer stand as opponents of change, particularly economic change and its social consequences. Economic change has become so central to political success that no serious party organisation can risk standing against it, as European conservatives once did. A key year in this history was 1959, when, in both Ireland and Spain, governing Catholic elites stopped allowing their (accurate) observation that industrialisation and general modernisation tended to weaken the power of the Church to stand in the way of embracing economic growth. Elsewhere, conservatives had dropped this stance much earlier. Today, when conservatives' role as the defenders of the privileged and economically successful has tied them strongly to neoliberal policies, their commitment to the other, Oakeshottian, face of their tradition has become difficult to sustain. Nowhere are conservative or Christian parties able to keep hold of anything like 50 per cent of the electorate, as they once did in several countries. In the USA, where the electoral system virtually enforces a two-party model, the Republicans are able to maintain such a position only at the expense of internal coherence.

Two things sustain modern conservatism. First, through its association with the powerful and successful, it can be an identity of aspiration, a symbol that one has distinguished oneself from the mass. Second, one aspect of traditional conservatism is by no means in decline: attachment to nation, and perhaps, through that, to race or ethnicity. Globalisation has broken many of the barriers that protected people from contact with those from other nations, more generally through trade and travel, more specifically through immigration and flows of refugees from troubled parts of the world. Conservatism's biggest single historical symbol is therefore enjoying growing salience. Through their endorsement of neoliberal change, conservatives help usher in globalisation, but through their identification with the nation they can then gain from the revived nationalism that opposition to globalisation stimulates. To benefit from the problems one causes is to be in an envious position indeed, but it comes at a price. Contemporary conservatives have been more or less inseparably tied to neoliberal economics, which would rule out responding to discontent by adopting economic protectionism and outright hostility to labour immigration. Do they, or at least some elements of them, now seek to depart from that association? If so, does this provide new scope for that forgotten fourth point on the political polygon: egalitarian conservative nationalism? 
This is not mere theoretical speculation. Several recent trends suggest this as a real possibility. The French Front National rejects all aspects of neoliberalism and mondialisation. Under the leadership of Marine Le Pen the party has gone further and developed strong social policies, seeking a place on the conservative-socialist limb of the triangle and eschewing all forms of liberalism. Similar developments have occurred in the xenophobic Dansk Folkeparti (Danish People's Party, DF), which supports a minority neoliberal-conservative coalition government, but which is strongly resisting cuts in the welfare budget. The fact that depressed working-class areas in England and Wales voted heavily for the UK to leave the European Union in the referendum of June 2016 led the prime minister, Theresa May, rapidly to develop a rhetoric that was explicitly both hostile to immigrants and sympathetic to the English poor. To date, British nationalists, whether within the Conservative party or in the United Kingdom Independence party (UKIP), have - unlike their Continental counterparts and the similar movement developed by Donald Trump in the USA - taken up strong free-market positions, hostile to protectionism and ambivalent about the welfare state. They have squared this circle by seeking to replace the country's membership of the EU with the creation of a new freetrade zone based primarily on the old British Empire. It remains to be seen whether this is a realistic project or a romantic dream. Meanwhile, there have been hints that the Conservative government's rediscovery of a working-class constituency might lead it in protectionist directions. At the time of writing, the main evidence for this is the pledge that has been made to the Nissan motor manufacturer that the government will take steps, currently kept secret, to ensure that its plant at Sunderland in the depressed northeast will not be adversely affected by Britain leaving the EU.

Far more problematic is whether the incipient egalitarian tendencies of these nationalistic movements stand any greater chance than their predecessors of remaining viable within the dominant anti-egalitarianism of far-right politics. Trump's presidency in the USA is committed to demolishing Obamacare and making the country's fiscal system even less progressive than it is now. The dominant 'hard Brexit' form of antiEuropeanism in the UK government seeks to expose the economy to a strong competitive shock, which will have some of its most negative consequences for the depressed postindustrial parts of the country in whose name Brexit is ostensibly being pursued.

If the main challenge to historical conservatism has come from changes in religious and other values, that to socialism and social democracy is more straightforwardly demographic: the decline of the industrial manual working class, the earlier growth of which had been inseparably linked to the rise of this form of politics. The new 'lower' classes formed by the post-industrial economy do not easily acquire a political identity. I have argued elsewhere that the social identities which people understand acquire political meaning only when they become the objects of struggles around exclusion and inclusion in citizenship. ${ }^{6}$ If one knows that it is because one has identity $X$ that one is excluded from certain badges of citizenship, one is likely to see a political meaning in that identity. (Vice versa, if one's identity $\mathrm{Y}$ enables one to enjoy certain privileges, one may well see it as important in political struggles to exclude those who do not possess that identity.) Class and religion were once central to many such conflicts. Without such powerful clues, it is not clear why people whose everyday lives do not bring them into contact with politics should see political implications in their social identities. They might vote, but not on the basis of powerful forces such as those which Matthew, McKibbin and Kay identified for the rising British working-class electorate-unless, as many of them seem likely to do, they turn to the promise of egalitarian conservative nationalism.

\section{The vortices of nationalism and neoliberal economics}

The state of politics to which we are moving can be summarised as follows. Liberalism is weak in terms of popular appeal, but, as neoliberalism, it dominates actual political decision-making in most societies, partly through the growing importance in postdemocratic societies of business lobbies in

Neoliberalism, Nationalism and the Decline of Political Traditions 227 
general and the financial sector in particular. Given both this power and its dependence on other traditions for a popular base for its agenda, it acts like a vortex pulling the others towards it. Conservatism is weakening in terms of its religious and traditionalist bases, but strengthening if it appeals to increasingly salient sentiments of nationalism and xenophobia, which form a second powerful vortex. Socialism or social democracy remains weak in itself and remote from the conservatism-liberalism limb of the triangle that links nationalism and neoliberalism, unless it too takes a xenophobic turn.

Coalitions within and among parties representing neoliberalism and conservatism are currently harnessing the two most powerful forces in politics, but this is an alliance of two horses going in divergent directions. The insistence on global free trade and free movement of all factors of production that is essential to the neoliberal project cannot coexist with nationalism and xenophobia, but in virtually all European countries (except Germany), established conservative parties are veering off towards various forms of nationalism, being led by the nose by newly important far-right parties. The pace of the divergent paths can vary considerably depending on context and different clusters of alliances. At what point do alliances with social democrats become more attractive to neoliberals, despite their preference for conservatives? For example, if the EU, European Central Bank and IMF continue with uncompromising neoliberal policies towards Greece, the extreme nationalist party Golden Dawn might become part of government, with an agenda more hostile to economic liberalism than that of the leftist Syriza. A different example concerns the UK. Although British conservatives do not understand the fact, their problem with European immigration is that the free movement of labour is solely a neoliberal right. It has granted workers a right to move across transnational European space but has developed hardly any European-level social citizenship to accompany it, throwing the whole burden onto national welfare systems that neoliberals prefer to pretend do not exist. The decision-making level that grants the right to move should also fund and administer the social support that migrant workers might need before they have participated sufficiently in their country of immigration to be entitled to share national citizenship rights. But this approach would require the mobility right to be one of social citizenship, not of the market alone. In both the Greek and the British cases, a return to the neoliberal-social democratic coalition that characterised the EU under the Delors and Prodi presidencies, before the more decisively neoliberal turn, might be necessary to ward off a growing nationalism that is beginning to threaten the whole European project. Of course, having more European social policy would have enraged British right-wing europhobes even more than the present arrangements, but it might have reduced their support within the wider population.

Social democrats and liberals have made effective common cause in the past, and recent agendas of change in gender and family-related policies have been their joint, anticonservative project. But in several countries social democrats have felt that they have in general had a poor deal from embracing a neoliberal turn. Important examples have been Germany under the Neue Mitte of Gerhard Schröder, the UK under Tony Blair's and Gordon Brown's New Labour and Matteo Renzi's government in Italy. Similar developments happened with Bill Clinton's New Democrats in the USA. There was electoral success, but disappointing substantive policies. As a declining popular force, social democracy is not in a position to demand big policy concessions. The chances of neoliberals and social democrats collaborating in national electoral politics therefore depend on the former being so appalled at the nationalist challenge that they make more concessions to the latter than might seem necessary. It is a different matter at the level of international organisations, where this remains the most viable policy combination.

Meanwhile, some social democrats are, in their disillusionment with neoliberal collaboration, looking in the opposite direction. Danish social democrats have suggested to the DF that they would make more logical coalition partners than the current neoliberal government that is trying to dismantle parts of the welfare state. Particularly innovative is the self-styled 'Blue Labour' phenomenon 
in the UK, founded by the Labour peer Maurice Glasman, which explores the conservative elements in Labour's tradition. ${ }^{7}$ It does this primarily through appeals at the level of communities and their traditions, whether local or in the form of different religious and ethnic groups, but there is also a distinct appeal to 'Britishness' - currently directed against the EU as such, but distinctly not against ethnic minorities or refugees. ${ }^{8}$ The current dominant conflict in the Labour party is a simpler one between right and left, obscuring the issues raised by Blue Labour. The Labour left and Blue Labour both criticise the way in which the neoliberalism of Conservative and New Labour governments helped destroy traditional working-class communities, but Blue Labour are not likely to see left-wing and state-centred policies as appealing to those communities. It may be trying instead to establish that problematic fourth point of a potential political square.

One can perhaps see a new assembly of political forces developing as modern conservatism divides into neoliberal and nationalist wings. Despite the strength of their alliance, in their uncompromised forms these constitute the two most opposed forces in contemporary politics: the former hostile to the welfare state and internationalist, the latter nationalist but potentially prowelfare. Curiously, social democracy, the centre-left, stands closer to both these forms of the right than they do to each other, sharing internationalism with liberals and the welfare state with many nationalist conservatives. This gives social democrats a potential role as power brokers, despite their state of historical decline. If some choose the latter alliance, what implications would it have for their traditional hostility to all forms of xenophobia? And does egalitarian conservative nationalism stand any better chance than its other historical forms of retaining autonomy from the more dominant anti-egalitarian ones?

\section{Notes}

1 D. Marquand, Mammon's Kingdom. An Essay on Britain, Now, London, Allen Lane, 2014.

2 M. Oakeshott, 'On being conservative', in Rationalism and Politics and Other Essays, London, Methuen, 1962.

3 A. Downs, 'An economic theory of political action in a democracy', Journal of Political Economy, vol. 65, 1957, pp. 135-50.

4 See, for example: OECD, In It Together: Why Less Inequality Benefits All, Paris, OECD, 2015; World Bank, Inequality in Focus, Washington DC, World Bank, 2014; A. G. Berg and J. D. Ostry, Inequality and Unsustainable Growth: Two Sides of the Same Coin? IMF Staff Discussion Note SDN/ 11/08, Washington DC, IMF, 2011.

5 H. C. G. Matthew, R. I. McKibbin and J. A. Kay, 'The franchise factor in the rise of the Labour party', The English Historical Review, vol. 91, no. 361, 1976, pp. 723-52.

6 C. Crouch, 'The march towards post-democracy, ten years on', The Political Quarterly, vol. 87, no. 1, 2016, pp. 71-5.

7 I. Geary and A. Pabst, eds., Blue Labour: Forging a New Politics, London, I. B. Tauris, 2015.

8 Glasman strongly supported the UK's withdrawal from the EU, but the organisation that he founded, Citizens UK, has been active in helping refugees trapped in Calais. Another prominent Blue Labour supporter, David Goodhart, also supported exit from the EU and has written about problems caused by high levels of immigration (The British Dream: Successes and Failures of Post-war Immigration, London, Atlantic Books, 2013). 